\title{
Assessment and kinetics of soil phosphatase in Brazilian Savanna systems
}

\author{
ADÃO S. FERREIRA ${ }^{1}$, SUÉLLEN P. ESPÍNDOLA ${ }^{1}$ and MARIA RITA C. CAMPOS ${ }^{2}$ \\ ${ }^{1}$ Instituto de Ciências Agrárias, Universidade Federal de Uberlândia, Rua Amazonas, s/n, 38400-902 Uberlândia, MG, Brasil \\ ${ }^{2}$ Instituto de Biotecnologia, Universidade Federal de Goiás/UFG, Campus Catalão, \\ Av. Dr. Lamartine Pinto de Avelar, 1120, 75704-020 Catalão, GO, Brasil \\ Manuscript received on January 24, 2014; accepted for publication July 17, 2015
}

\begin{abstract}
The activity and kinetics of soil phosphatases are important indicators to evaluate soil quality in specific sites such as the Cerrado (Brazilian Savanna). This study aimed to determine the activity and kinetic parameters of soil phosphatase in Cerrado systems. Soil phosphatase activity was assessed in samples of native Cerrado (NC), no-tillage (NT), conventional tillage (CT) and pasture with Brachiaria brizantha $(\mathrm{PBb})$ and evaluated with acetate buffer (AB), tris-HCl buffer (TB), modified universal buffer (MUB) and low MUB. The Michaelis-Menten equation and Eadie-Hofstee model were applied to obtain the kinetic parameters of soil phosphatase using different concentrations of p-nitrophenol phosphate (p-NPP). MUB showed the lowest soil phosphatase activity in all soils whereas AB in NC and NT presented the highest. Low MUB decreased interferences in the assessment of soil phosphatase activity when compared to MUB, suggesting that organic acids interfere on the soil phosphatase activity. In NC and NT, soil phosphatase activity performed with $\mathrm{TB}$ was similar to $\mathrm{AB}$ and low MUB. $\mathrm{K}_{\mathrm{m}}$ values from the Michaels-Menten equation were higher in $\mathrm{NC}$ than in NT, which indicate a lower affinity of phosphatase activity for the substrate in NC. $\mathrm{V}_{\max }$ values were also higher in NC than in NT. The Eadie-Hofstee model suggests that NC had more phosphatase isoforms than NT. The study showed that buffer type is of fundamental importance when assessing soil phosphatase activity in Cerrado soils.
\end{abstract}

Key words: soil phosphatase activity, buffer, enzyme kinetics, Michaelis-Menten equation, Eadie-Hofstee model, Cerrado.

\section{INTRODUCTION}

Phosphorus (P) availability in soils depends on phosphorus recycling from soil organic matter (Tabatabai and Bremner 1969, Albrecht et al. 2010, Brooks et al. 2013). This availability is also regulated by adsorption of phosphate anions to aluminum and iron oxide compounds present

Correspondence to: Adão de Siqueira Ferreira

E-mail: adaosferreira@yahoo.com in soils (Cleveland et al. 2002, Novais and Smith 1999, Sylvia et al. 1999). Nevertheless, soil organic phosphorus mineralization is an enzymatic process carried out by a group of phosphatases that catalyze hydrolytic reactions of phosphate groups (mono or diesters), thereby providing inorganic $\mathrm{P}$ to the soil solution (Neble et al. 2007, Criquet and Braud 2008, Tabatabai 1994). Acid phosphatase activity in particular plays an important role in hydrolyzing organic phosphorus to orthophosphate ions in acid 
soils (Tabatabai 1994, Huang and Shindo 2000), including soils of the Cerrado (Vinhal-Freitas et al. 2012).

Soil phosphatase is a primary indicator of soil quality in various land use systems (Dick 1997, Vinhal-Freitas et al. 2013). Although many studies have examined enzymes in Brazilian soils (Vinhal-Freitas et al. 2010, 2012, Pavanelli and Araújo 2010), they have not explored Michaelis-Menten constants. Kinetic parameters can provide important information on the enzymatic mechanisms and soil functions in ecosystems (Nannipieri et al. 1982, Marx et al. 2001, Vinhal-Freitas et al. 2013). Enzyme kinetic parameters are affected by specific soil conditions such as metabolite concentration, microbial community, salinity, metals, and soil $\mathrm{pH}$ (Nannipieri and Gianfreda 1998, Marx et al. 2001, Nannipieri et al. 1982). These conditions are greatly affected by the land use, including soil management practices (Nannipieri et al. 1982). Soil enzyme analysis also varies with the $\mathrm{pH}$, reaction buffer and substrate concentration (Malcom 1983, Nannipieri et al. 1982).

In most studies, soil phosphatase activity is determined by using the substrate $\mathrm{p}$-nitrophenol phosphate ( $\mathrm{p}$-NPP) in modified universal buffer (MUB) as described by Tabatabai and Bremer (1969). However, in Cerrado soils this methodology tends to underestimate the phosphatase activity in colorimetric assays. Reports have shown that high levels of soil organic matter, iron and aluminum can interfere in colorimetric assays (Trasar-Cepeda and Gil-Sotres 1988, Malcom 1983). Cerrado soils are acidic, highly weathered, contain high levels of iron and aluminum (Ferreira et al. 2008, VinhalFreitas et al. 2012), and may possess organic content as high as of native forest soils. Thus, the existing procedures for determining phosphatase activity in Cerrado soils should be reviewed. Due to the properties described above, it is hypothesized that, in spite of its use in many studies, MUB is inadequate for assessing the phosphatase activity in Cerrado soils when sodium hydroxide is used to extract p-nitrophenol (p-NP).

The objective of this study was to determine the activity and kinetic parameters of soil phosphatase in native and agricultural soils of the Brazilian Savanna. Additionally, four different buffers were applied in order to evaluate sensitivity of soil phosphatase activity measurement in colorimetric assays.

\section{MATERIALS AND METHODS}

The study was carried out in natural and agricultural sites in the Cerrado ecoregion near Uberlândia (Minas Gerais state, Brazil). Based on precipitation and temperature, the region's climate was classified as "Cwa" (Köppen 1923). Specifically, the climate is "hot moderate" with a very dry winter and a warm, rainy summer. The soils were classified as clayey Oxisol (Typic Acrustox) according to Soil Taxonomy (USDA 1992). In the summer of 2012, soil samples of $600 \mathrm{~cm}^{2}(20 \mathrm{~cm} \times 30 \mathrm{~cm})$ were taken at a depth of $5 \mathrm{~cm}$. The sample points were randomly selected within a 1 ha area following a $\mathrm{W}$ sampling scheme. After removing organic litter, five soil samples were collected at each site. Three subsamples were collected at each sampling point and mixed into one sample. Samples were transported to the laboratory in isothermic bags (4 $\left.{ }^{\circ} \mathrm{C}\right)$. Each sample was sieved $(\sim 3 \mathrm{~mm})$ and stored at $4{ }^{\circ} \mathrm{C}$ until the day of analysis (within a maximum of two weeks). Moisture content was measured after oven drying for $48 \mathrm{~h}$ at $105^{\circ} \mathrm{C}$. Additional physicochemical characteristics of the air-dried soil were also analyzed (Table I). Microbial biomass carbon (Ferreira et al. 1999) and microbial respiration (Stotzky 1965) were determined using moist soil and the results were adjusted to dry weight (Table I).

Soil phosphatase activity was determined in a spectrophotometric assay (405 nm) by quantifying the $\mathrm{p}-\mathrm{NP}$ ( $\mathrm{p}$-nitrophenol) released from $\mathrm{p}-\mathrm{NPP}$ (p-Nitrophenol phosphate) substrate using differ- 
TABLE I

Physicochemical characteristics of soils under different land-use systems.

\begin{tabular}{lcccc}
\hline \multirow{2}{*}{ Characterization } & \multicolumn{4}{c}{ System } \\
\cline { 2 - 5 } & $\mathrm{NC}$ & $\mathrm{NT}$ & $\mathrm{CT}$ & $\mathrm{PBb}$ \\
\hline Sand $\left(\mathrm{g} \mathrm{kg}^{-1}\right)$ & 135 & 140 & 120 & 550 \\
Clay + Silte $\left(\mathrm{g} \mathrm{kg}^{-1}\right)$ & 865 & 860 & 880 & 450 \\
Carbon $\left(\mathrm{g} \mathrm{C} \mathrm{kg}^{-1}\right)$ & 48.2 & 30.3 & 23.5 & 26.8 \\
Nitrogen $\left(\mathrm{mg} \mathrm{N} \mathrm{kg}^{-1}\right)$ & 3.24 & 1.93 & 0.98 & 0.70 \\
Phosphorus $\left(\mathrm{mg} \mathrm{P} \mathrm{kg}^{-1}\right)$ & 1.89 & 8.29 & 3.26 & 2.06 \\
Potassium $\left(\mathrm{mg} \mathrm{K} \mathrm{kg}^{-1}\right)$ & 37 & 106 & 70 & 60 \\
pH H $\mathrm{O}$ & 4.0 & 6.5 & 6.3 & 6.0 \\
MBC (mg C kg & 559 & 297 & 186 & 249 \\
$\mathrm{BRS}\left(\mathrm{mg} \mathrm{C} \mathrm{day}^{-1} \mathrm{~kg}^{-1}\right.$ dry soil & 89 & 13.3 & 6.8 & 24.8 \\
\hline
\end{tabular}

$\mathrm{MBC}$, microbial biomass carbon. BRS, basal respiration of soil. NC, native Cerrado; NT, no-tillage; CT, conventional tillage. PBb, Pasture with Brachiaria brizantha.

ent buffers ( $\mathrm{pH}$ 6.5). A $1 \mathrm{~g}$ portion of wet soil was transferred into a Falcon tube $(50 \mathrm{~mL})$ and $4 \mathrm{~mL}$ of buffer and $1 \mathrm{~mL}$ of p-NPP substrate $(7.5 \mathrm{mM}$ of 4-Nitrophenyl phosphate disodium salt hexahydrate diluted in buffer) were added. Controls without p-NPP were assayed for each soil sample in order to determine a baseline for the buffer's effect. Reaction mixtures were incubated at $37{ }^{\circ} \mathrm{C}$ for 1 hour and then calcium chloride $\left(0.5 \mathrm{M} \mathrm{CaCl}_{2}\right)$ was added. The reaction was stopped by adding 4 $\mathrm{mL}$ of sodium hydroxide $(0.5 \mathrm{M})$. An aliquot of the extract $(2 \mathrm{~mL})$ was centrifuged at $10,000 \mathrm{x}$ g for 2 minutes and then analyzed in a spectrophotometer (Biomate 3, Thermo Scientific).

Four different buffers were used to assess phosphatase activity in order to evaluate the effect of buffer type on the results. The four buffers used were prepared as follows:

(AB) - Acetate buffer $(0.5 \mathrm{M}): 41 \mathrm{~g}$ of sodium acetate were transferred to $800 \mathrm{~mL}$ MilliQ water and then adjusted to $\mathrm{pH} 6.5$ with hydrochloric acid $(10 \mathrm{M})$. The mixture was transferred into a volumetric flask $(1 \mathrm{~L})$ and the volume completed with MilliQ water.

(TB) - Tris-Buffer $(0.5 \mathrm{M}): 60.5 \mathrm{~g}$ of tris (hydroxymethylaminomethane) were transferred to $800 \mathrm{~mL}$ MilliQ water and then adjusted to $\mathrm{pH} 6.5$ with hydrochloric acid (10 M). The mixture was transferred into a volumetric flask ( $1 \mathrm{~L})$ and the volume completed with MilliQ water.

(MUB) - Modified Universal Buffer: 2.42 $\mathrm{g}$ of tris (hydroxymethylaminomethane), $2.3 \mathrm{~g}$ of maleic acid, $2.8 \mathrm{~g}$ of citric acid and $1.26 \mathrm{~g}$ of boric acid were transferred to $800 \mathrm{~mL}$ MilliQ water and then adjusted to $\mathrm{pH} 6.5$ with sodium hydroxide (10 $\mathrm{M})$. The mixture was transferred into a volumetric flask (1 L) and the volume completed with MilliQ water.

(low MUB) - low Modified Universal Buffer: $0.2 \mathrm{~g}$ of tris (hydroxymethylaminomethane), 1.15 of maleic acid, $1.4 \mathrm{~g}$ of citric acid and $0.618 \mathrm{~g}$ of boric acid were transferred to $800 \mathrm{~mL}$ MilliQ water and then adjusted to $\mathrm{pH} 6.5$ with sodium hydroxide $(10 \mathrm{M})$. The mixture was transferred into a volumetric flask (1 L) and the volume completed with MilliQ water.

The standard curves of each buffer was performed. An extraction solution containing $40 \mathrm{~mL}$ $\mathrm{NaOH}(0.5 \mathrm{M})$ and $50 \mathrm{~mL}$ of each buffer was prepared under the same conditions of the soil sample. A portion of p-NP $(0.2 \mathrm{~g})$ was transferred into a volumetric flask $(50 \mathrm{~mL})$ and the volume completed with extraction solution. This solution $(5 \mathrm{~mL})$ was diluted in another volumetric flask $(50 \mathrm{~mL})$ and completed with the extraction solution. The final solution was diluted another time with the same 
procedure. After, aliquots of 125, 250, 500, 1,000 and 2,000 $\mathrm{mL}$ were transferred to a volumetric flask $(10 \mathrm{~mL})$ and the volume was completed with the extraction solution. The final concentrations ranged from 0.5 to $8 \mathrm{ug} \mathrm{p}-\mathrm{NP} \mathrm{mL}^{-1}$. Each point, including the control, was measured in the spectrophotometer.

After the extraction with $\mathrm{NaOH}(0.5 \mathrm{M})$, the assay tubes were photographed (Canon digital camera) in order to show the sample staining with the use of different buffers. The results were analyzed by determining the confidence intervals of samples ( $p$ <.005). Michaelis-Menten (1) and Eadie-Hofstee (2) equations were used in the modelling of data and determination of kinetic parameters of the phosphatase activity:

$\mathrm{V}=\left(\mathrm{V}_{\max } \mathrm{x}[\mathrm{S}]\right) /\left(\mathrm{K}_{\mathrm{m}}+[\mathrm{S}]\right)$

$\mathrm{V}=-\mathrm{K}_{\mathrm{m}} \mathrm{V} /[\mathrm{S}]+\mathrm{V}_{\max }$

where $\mathrm{V}$ is the reaction rate of release $\mathrm{p}-\mathrm{NP}, \mathrm{V}_{\max }$ is the maximum phosphatase activity, $[\mathrm{S}]$ is the substrate concentration ( $p-N P P$ ) and $K_{m}$ is the Michaelis-Menten constant. Equation parameters and statistical significance were determined using the software SigmaPlot 12.0.

\section{RESULTS}

The results show that the phosphatase activity measured depends on buffer type. The buffer also affected the coloring of the control samples (without substrate). MUB caused the greatest change in the absorbance values of the controls (Table II). These values were high, but especially for the NC samples. Figure 1 (a) shows the color of the extract in the control and the substrate (p-NPP) samples. Notably, MUB strongly interfered the measure of phosphatase activity, whereas low MUB minimized this interference. The coloring of the MUB samples remained high also after centrifugation (Fig. 1b).

Buffer resolutions were estimated using a standard curve with p-NP (Table III). The regression coefficients $\left(\mathrm{R}^{2}\right)$ for all buffers were high and significant. However, TB resolution was higher than for other buffers and 15\% higher than $\mathrm{AB}$. MUB and low MUB resolutions were similar. The sensitivity quantifications were 7.6 and $8.9 \mathrm{ng} \mathrm{p}-\mathrm{NP} \mathrm{mL}^{-1}$ for the standard curves of $\mathrm{AB}$ and $\mathrm{TB}$, respectively.

In the assays, the phosphatase activity of all soils ranged from 87 to $795 \mathrm{ug} \mathrm{p}-\mathrm{NP} \mathrm{g}^{-1}$ dry soil. The highest phosphatase activity in NC was observed with $\mathrm{AB}$ while the lowest with MUB (Table IV). MUB had the greatest standard deviation in soil phosphatase activity. The NT system had the second highest average phosphatase activity and showed with MUB the lowest activity in this system. Compared to MUB, low MUB decreased the variation in the phosphatase activity but still produced lower activity values than $\mathrm{TB}$ and $\mathrm{AB}$. Finally, when the phosphatase activity was low, differences between buffers were not significant.

TABLE II

Absorbance values of control samples (without substrate) in each buffer ${ }^{1}$ and agricultural systems ${ }^{2}$.

\begin{tabular}{lllll}
\hline \multirow{2}{*}{ System } & \multicolumn{3}{l}{ Buffer } \\
\cline { 2 - 5 } & $\mathrm{AB}$ & $\mathrm{TB}$ & MUB & low MUB \\
\hline $\mathrm{NC}$ & $0.034 \pm 0.013$ & $0.016 \pm 0.008$ & $0.365 \pm 0.053$ & $0.040 \pm 0.007$ \\
$\mathrm{NT}$ & $0.005 \pm 0.004$ & $0.003 \pm 0.007$ & $0.065 \pm 0.007$ & $0.018 \pm 0.004$ \\
$\mathrm{CT}$ & $0.010 \pm 0.004$ & $0.002 \pm 0.016$ & $0.040 \pm 0.016$ & $0.017 \pm 0.009$ \\
$\mathrm{PBb}$ & $0.012 \pm 0.005$ & $0.003 \pm 0.009$ & $0.043 \pm 0.009$ & $0.023 \pm 0.010$ \\
\hline
\end{tabular}

${ }^{1}$ Buffers used in assays: $\mathrm{AB}$, acetate buffer; $\mathrm{TB}$, Tris-HCl buffer; MUB, modified universal buffer (MUB); low MUB, low modified universal buffer.

${ }^{2} \mathrm{NC}$, native Cerrado; NT, no-tillage; CT, conventional tillage. PBb, Pasture with Brachiaria brizantha. 

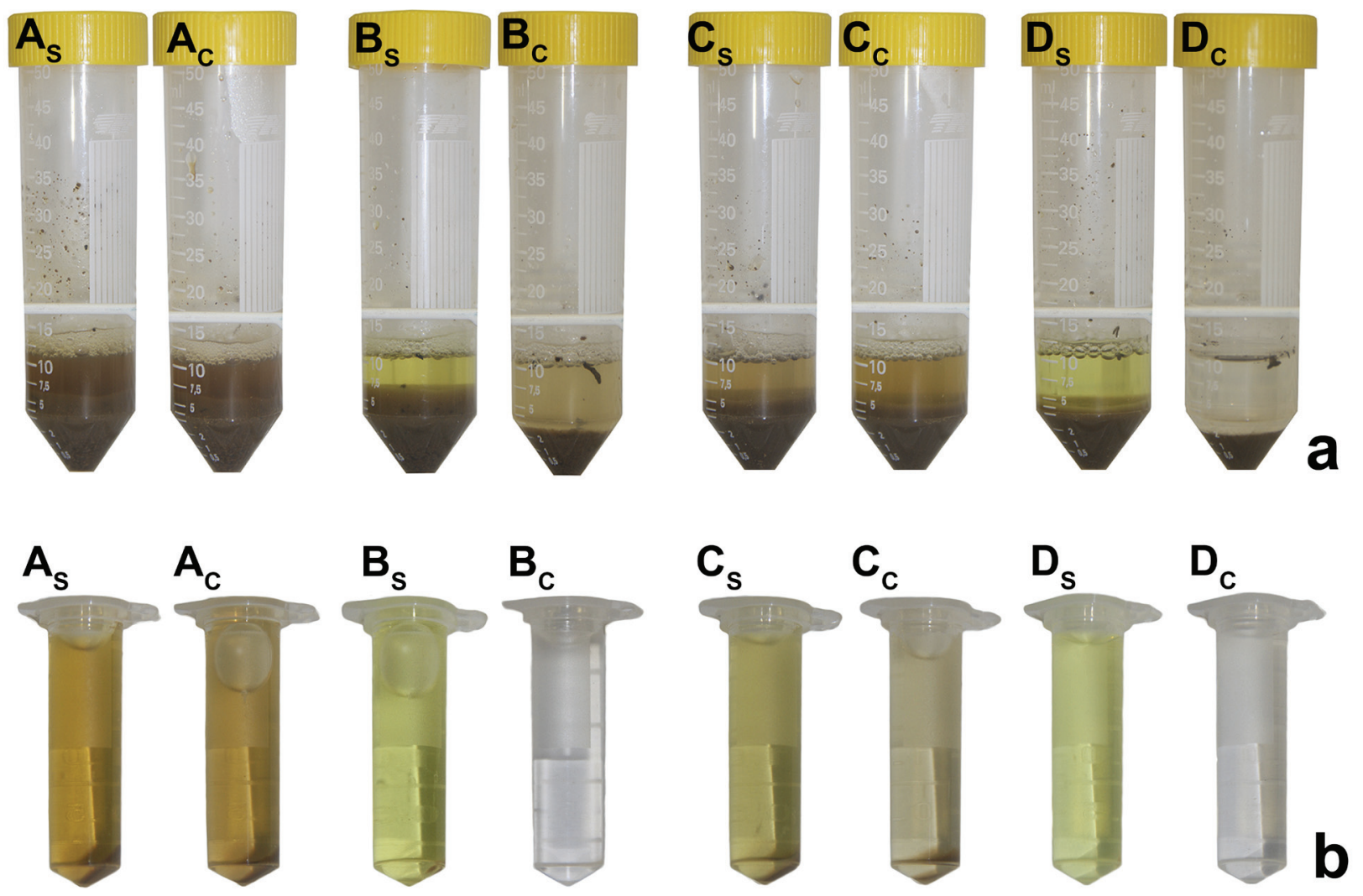

Figure 1 - Interference MUB and low MUB in the staining of control (without) samples and substrate samples in the enzyme extract before (a) and after centrifugation (b). Substrate samples showed in $\mathrm{A}_{\mathrm{s}}, \mathrm{B}_{\mathrm{s}}, \mathrm{C}_{\mathrm{s}}$ and $\mathrm{D}_{\mathrm{s}}$ and control samples showed in $\mathrm{A}_{\mathrm{c},} \mathrm{B}_{\mathrm{c}}$, $\mathrm{C}_{\mathrm{c}}$ and $\mathrm{D}_{\mathrm{c}}$. Letters $\mathrm{A}_{\mathrm{s}}, \mathrm{A}_{\mathrm{c}}, \mathrm{B}_{\mathrm{s}}$ and $\mathrm{B}_{\mathrm{c}}$ shows the staining in the native Cerrado (NC) and $\mathrm{C}_{\mathrm{s}}, \mathrm{C}_{\mathrm{c}}, \mathrm{D}_{\mathrm{s}}$ and $\mathrm{D}_{\mathrm{c}}$ in no-tillage (NT). MUB is identified as $A_{s}, A_{c}, C_{s}$ and $C_{c}$ and low MUB is identified as $B_{s}, B_{c}, D_{s}$ and $D_{c}$. (See the colors in the online version).

TABLE III

Parameters of equation used to estimate the p-NP of standard curves in each buffer ${ }^{1}$.

\begin{tabular}{llll}
\hline Buffer & Equation & $\mathrm{R}^{2}$ & $\mathrm{p}$ \\
\hline $\mathrm{AB}$ & $\mathrm{y}=0.1897 \mathrm{x}-0.0044$ & 0.9999 & $<0.001$ \\
TB & $\mathrm{y}=0.1614 \mathrm{x}-0.0043$ & 0.9998 & $<0.001$ \\
MUB & $\mathrm{y}=0.1726 \mathrm{x}-0.0024$ & 0.9999 & $<0.001$ \\
low MUB & $\mathrm{y}=0.1735 \mathrm{x}-0.0038$ & 0.9999 & $<0.001$ \\
\hline
\end{tabular}

${ }^{1}$ Buffers used in assays: AB, acetate buffer; TB, Tris-HCl buffer; MUB, modified universal buffer (MUB); low MUB, low modified universal buffer.

The kinetic parameters of soil phosphatase were evaluated in two systems ( $\mathrm{NC}$ and NT) because they belong to the same soil class and presented the highest enzymatic activity. The $\mathrm{V}_{\max }$ of soil phosphatase in NC was 3.59 times higher than in $\mathrm{NT}$, and $\mathrm{K}_{\mathrm{m}}$ was 2.45 times greater than in NC (Fig. 2). The regression coefficients $\left(\mathrm{R}^{2}\right)$ of both systems were high and significant $(\mathrm{p}<0.0001)$ what indicates that the Michaelis-Menten equation is appropriate for soil data from the Cerrado. The Eadie-Hofstee equation also showed significant differences between the systems with a regression coefficient $\left(\mathrm{R}^{2}\right)$ of 0.72 for NC and 0.88 for NT (Fig. $3 \mathrm{a}, \mathrm{b})$. The variation coefficient (\%) was higher in $\mathrm{NC}$ than in the NT system, whichjustifying the $\mathrm{R}^{2}$ values. 
TABLE IV

Soil phosphatase activity ${ }^{1,2}$ (ug p-NP g ${ }^{-1}$ dry soil) obtained with different buffers ${ }^{3}$ and under different landuse systems $(n=5)$.

\begin{tabular}{lllll}
\hline \multirow{2}{*}{ System } & \multicolumn{4}{c}{ Buffer } \\
\cline { 2 - 5 } & AB & TB & MUB & low MUB \\
\hline NC & $519 \pm 85(16)$ & $305 \pm 80(26)$ & $207 \pm 103(49)$ & $225 \pm 63(28)$ \\
NT & $185 \pm 8.3(4.5)$ & $179 \pm 7.5(4.1)$ & $151 \pm 22(14)$ & $170 \pm 19(11)$ \\
CT & $120 \pm 6.1(5.1)$ & $142 \pm 13(9.1)$ & $133 \pm 20(15)$ & $128 \pm 6.9(5.4)$ \\
PBb & $103 \pm 9.2(8.9)$ & $117 \pm 9.2(7.8)$ & $112 \pm 10(8.9)$ & $95 \pm 3.2(3.3)$ \\
\hline
\end{tabular}

${ }^{1}$ Mean the soil phosphatase activity with standard deviation $( \pm \mathrm{SD})$.

${ }^{2}$ Values inside brackets indicate the percentage (\%) of sampling variation (standard deviation) in relation to the average of soil phosphatase activity of each buffer. NC, native Cerrado; NT, no-tillage; CT, conventional tillage; $\mathrm{PBb}$, Pasture with Brachiaria brizantha.

${ }^{3}$ Buffers used in assays: AB, acetate buffer; TB, tris-HCl buffer; MUB, modified universal buffer (MUB); low MUB, low modified universal buffer.

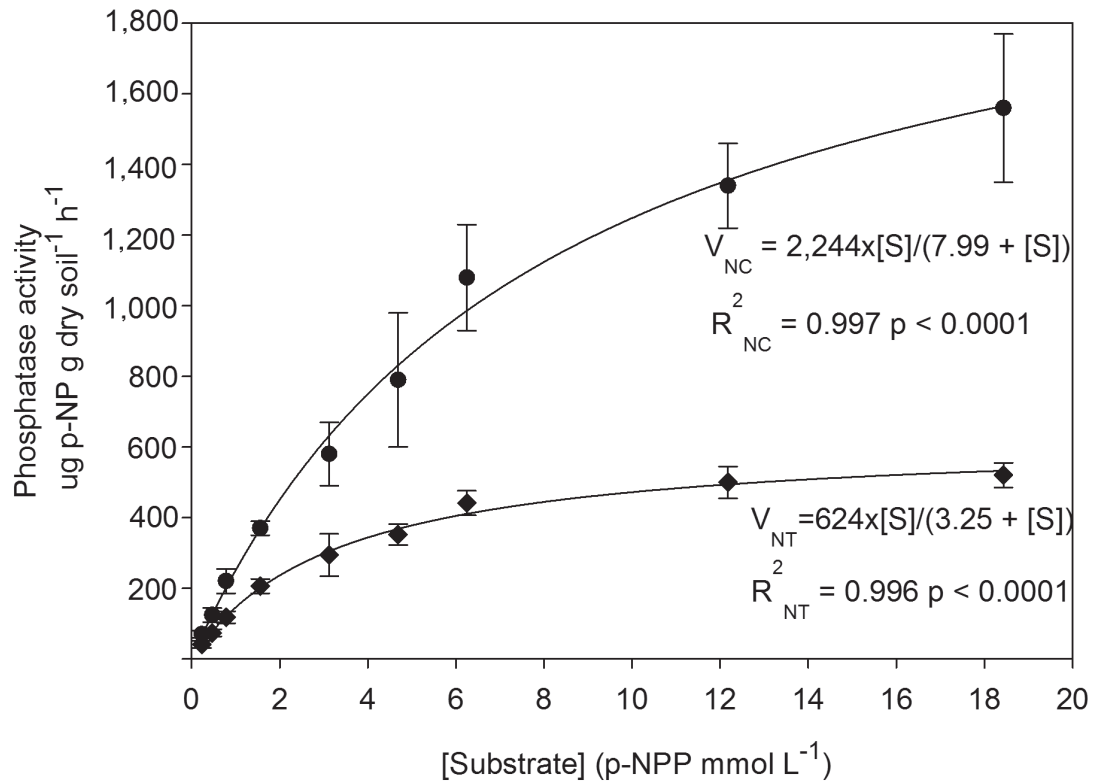

Figure 2 - Regression analysis of soil phosphatase activity using the Michaelis-Menten equation in the native Cerrado (NC) and no-tillage (NT). Where, $\mathrm{V}_{\mathrm{NC}}$ shows soil phosphatase activity in the native Cerrado (Circle) and $\mathrm{V}_{\mathrm{NT}}$ shows soil phosphatase activity in no-tillage (Diamond) as a function of substrate (S) concentration. Values of determination coefficient $\left(\mathrm{R}^{2}\right)$ and significant level of each equation $(\mathrm{p}<0.001)$ are also shown.

\section{DISCUSSION}

This study shows that phosphatase activity in Cerrado soil samples differs with the buffer applied in measurements. Phosphatase activity in NC soil samples cannot be estimated with the buffer used by Tabatabai and Bremner (1969) because the staining of the control (without substrate) and substrate samples is similar (Fig. 1). In all soil samples, phosphatase activity with MUB was lower than the other buffers.

Many factors influence the measurement of the soil phosphatase activity when using p-NPP as substrate (Brooks et al. 2013, Tabatabai and 

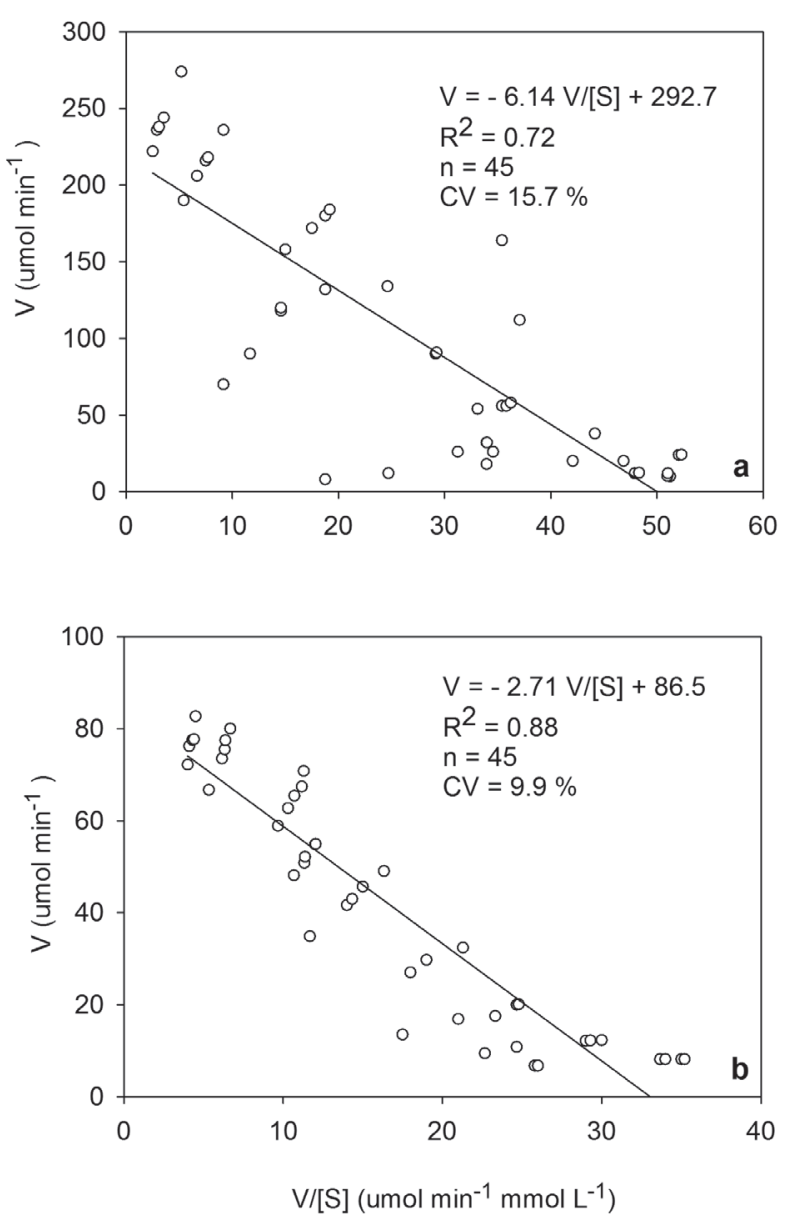

Figure 3 - Regression analysis of soil phosphatase activity using the Eadie-Hofstee model in the native Cerrado (a) and no-tillage (b). Where, values of determination coefficient $\left(\mathrm{R}^{2}\right)$, Coefficient of variation (CV \%) and number of sampling (n) are shown. Parameters of equations of Eadie-Hofstee model are significantly fitted at a probability level of $1 \%$.

Bremner 1969, Pettit et al. 1977, Tabatabai 1994). However, the clay content and level of humic acids are considered the most important because they interfere with the coloring extract containing p-NP (Pettit et al. 1977, Malcom 1983, TrasarCepeda and Gil-Sotres 1988). The addition of $\mathrm{CaCl}_{2}$ reduces the dispersion of clay and mitigates the interference in the extraction of $\mathrm{p}$-NP with $\mathrm{NaOH}$. Thus, $\mathrm{CaCl}_{2}$ was added to all buffers used to assess soil phosphatase activity to eliminate the potential interference from clay. All four soil types evaluated in this study were characterized as clayey. Nevertheless, interference from clay was only observed in two of the soils (soil from the NC and NT systems). It is believed that, in this study's assays, soil organic matter content was the main cause of interference in NC and NT when MUB was used. This may be because MUB contains acids (citric, boric and maleic), which can extract and disperse great amounts of humic acids from the soil organic matter. Furthermore, the addition of $\mathrm{NaOH}$ could also cause humic acid extraction under MUB conditions.

In the assays of this study, low MUB significantly reduced variations in soil phosphatase activity when compared to MUB, and resulted in higher enzyme activity in NC and NT. This reduction in variation is believed to occur because low MUB contains lower acid levels (citric, maleic and boric acids) than MUB. Low MUB also reduced tris levels in comparison to MUB. Nevertheless, tris$\mathrm{HCl}$ is not believed to interfere in the assessment of soil phosphatase activity. Additionally, soil phosphatase activity was higher with TB than with low MUB. In fact, the results show that $\mathrm{TB}$ has a higher resolution to quantify $\mathrm{p}$-NP in the final extract. Tris- $\mathrm{HCl}$ buffer has commonly been used to assess soil enzymes, including acid and alkaline soil phosphatase activity (Gerritse and van Duk 1978, Geller and Ginzburg 1979, Hui et al. 2013).

The results show that use of $\mathrm{AB}$ resulted in higher phosphatase activity measurements in NC and NT soils than the other buffers (Table III). However, AB produced results similar to other buffers when all measurements of soil phosphatase activity were low. Thus, it is concluded that $\mathrm{AB}$ may produce more accurate assessments of soil phosphatase activity when enzyme activity is high. Several factors can affect soil phosphatase activity during the assays, including organic matter, microbial biomass and root density (Fioretto et al. 2009, Brooks et al. 2013). This study did not determine the factors that cause differences in phosphatase activity. However, the data showed 
that soils from NC and NT systems have higher microbial biomass carbon. Higher soil phosphatase activity with $\mathrm{AB}$ could also be explained by specific factors, such as the extraction of intracellular phosphatase, isoenzymes and conditions affecting the enzyme activity in NC and NT systems.

The Michaelis-Menten equation showed a significant difference between NC and NT (Fig. 2). Kinetic parameters $\left(\mathrm{K}_{\mathrm{m}}\right.$ and $\left.\mathrm{V}_{\text {max }}\right)$ of soil phosphatase activity were higher in NC than in NT. Low values of $\mathrm{K}_{\mathrm{m}}$, in particular, indicate that the substrate has a higher affinity for the soil phosphates. Soil heterogeneity and multiple enzymes catalyzing the same reaction are factors that reduce enzymesubstrate affinity due to enzyme immobilization in soil constituents (e.g., organic matter and clay) and isoenzyme production (mainly by microorganisms). The results of this study are consistent with those reported in the literature, which show that more complex soils have greater $\mathrm{K}_{\mathrm{m}}$ and $\mathrm{V}_{\text {max }}$ values. On the other hand, high $\mathrm{V}_{\max }$ indicates that a soil has a greater capacity to provide $\mathrm{P}$ for plants and soil microorganisms by transforming various organic-P sources into inorganic-P.

The Eadie-Hofstee model shows specific parameters for enzymatic reactions of soil phosphatase activity in NC and NT systems (Fig. 3). The results show that the NT system has less variation and greater specificity between phosphatase activity and substrate than the NC system. This model uses the most sensitive parameters to assess kinetic variation in the Michaelis-Menten equation (Irving and Cosgrove 1976, Segel 1975). In addition to a specific enzyme-substrate, the Eadie-Hofstee model is also appropriate for enzyme isoforms (e.g., soil phosphatase). The model suggests that enzyme isoforms lead to a greater variation in the equation due to specificities of isoenzymes for the substrate. This studyemphasizes the importance of conducting comparative studies on soil phosphatase activity in various land use systems using kinetic models to assess soil enzyme activity.
The Brazilian Cerrado has a semi-humid tropical climate and is therefore one of the most humid Savanna regions. Tillage in the Cerrado has increased since the 1970s. However, since the 1990 s, the alternative practice of no-tillage (NT) has been incorporated into the Brazilian agriculture. NT currently accounts for approximately $90 \%$ of the area cultivated with annual crops (an estimated 31 million ha). Most soils in this region are deep, weathered, porous Oxisols with clay content greater than 15\% (Vinhal-Freitas et al. 2012). Standardizing enzyme activity in Cerrado soils is fundamental to further comparative studies. Moreover, the kinetic parameters of enzymes enlighten over the agroecosystem function. Determining the kinetic parameters, beyond simple measurements of enzyme activity, is important for understanding enzyme mechanisms, enzyme roles in specific soil conditions, enzyme responses to changes in metabolite concentration and also enzyme control mechanisms (Marinari et al. 2008, Henry 2012).

\section{CONCLUSIONS}

The study showed that the buffer type is of fundamental importance in order to assess the soil phosphatase activity in Cerrado soils. MUB showed the lowest soil phosphatase activity whereas $\mathrm{AB}$ in NC and NT the highest. Low MUB caused less interference in the measurement of soil phosphatase activity when compared to MUB. In NC and NT, soil phosphatase activity with $\mathrm{TB}$ was similar to $\mathrm{AB}$ and low MUB. There was no difference of buffer type for assessment the soil phosphatase activity in $\mathrm{CT}$ and $\mathrm{PBb} . \mathrm{K}_{\mathrm{m}}$ values from MichaelsMenten equation were higher in NC than in NT, showing a lower affinity of phosphatase activity for the substrate in $\mathrm{NC} . \mathrm{V}_{\max }$ values were also higher in $\mathrm{NC}$ than in NT. The Eadie-Hofstee model suggests that NC had more phosphatase isoforms than NT. Thus, for the sites considered in this study, soil phosphatase activity depends on the buffer type and the kinetic parameters depend on the land use. 


\section{ACKNOWLEDGMENTS}

The study was financially supported by the Fundação de Amparo à Pesquisa do Estado de Minas Gerais (FAPEMIG).

\section{RESUMO}

A atividade e cinética das fosfatases do solo são importantes indicadores para avaliar a qualidade do solo em sítios específicos tais como Cerrado (Savana brasileira). Este estudo objetivou determinar a atividade e os parâmetros cinéticos da fosfatase do solo em sistemas do Cerrado. A atividade de fosfatase do solo foi avaliada em amostras de Cerrado nativo $(\mathrm{CN})$, plantio direto (PD), plantio convencional (PC) e pastagem com Brachiaria brizantha (PBb) e avaliada com tampão de acetato (TA), tampão tris-HCl (TT), tampão modificado universal (TMU) e baixo-TMU. A equação de Michaelis-Menten e o modelo de Eadie-Hofstee foram usados para avaliar os parâmetros cinéticos da fosfatase do solo usando diferentes concentrações de p-nitrofenol fosfato (p-NFF). O TMU indicou a menor atividade de fosfatase do solo, enquanto que TA em $\mathrm{CN}$ e $\mathrm{PC}$, a maior atividade. O baixo-TMU diminuiu as interferências na avaliação da atividade de fosfatase do solo quando comparado à TMU, sugerindo que ácidos orgânicos interferem na atividade da fosfatase do solo. Em CN e PD, a atividade de fosfatase do solo com TT foi similar à TA e baixo-TMU. Os valores de $\mathrm{K}_{\mathrm{m}}$ da equação de Michaelis-Menten foram maiores em $\mathrm{CN}$ do que em PD, indicando menor afinidade da atividade de fosfatase para o substrato em $\mathrm{CN}$. Os valores de $\mathrm{V}_{\max }$ foram também maiores em $\mathrm{CN}$ quando comparados com PD. O modelo de Eadie-Hofstee indicou que $\mathrm{CN}$ tem mais isoformas de fosfatase no solo quando comparado com PD. O estudo mostrou que o tipo de tampão é de fundamental importância para avaliar a atividade de fosfatase em solos de Cerrado.

Palavras-chave: atividade de fosfatase do solo, tampão, cinética de enzima, equação de Michaelis-Menten equation, modelo de Eadie-Hofstee, Cerrado.

\section{REFERENCES}

Albrecht R, Petitt JL, CAlvert V, Terrom GR AND RISSOL PC. 2010. Changes in the level of alkaline and acid phosphatase activities during green wastes and sewage sludge co-composting. Bioresour Technol 101(1): 228233.

BROOKS DD, TWIEG BD, GRAYSTON SJ AND JONES MD. 2013. Physical extent, frequency, and intensity of phosphatase activity varies on soil profiles across a Douglas-fir chronosequence. Soil Biol Biochem 64: 1-8.

Cleveland CC, TOWNSEND AR AND SCHMIDT SK. 2002. Phosphorus limitation of microbial processes in moist tropical forests: evidence from short-term laboratory incubations and field studies. Ecosystems 5(7): 680-691.

CRIQUET S AND BRAUD A. 2008. Effects of organic and mineral amendments on available $\mathrm{P}$ and phosphatase activities in a degraded Mediterranean soil under shortterm incubation experiment. Soil Till Res 98(2): 164-174.

DICK RP. 1997. Soil enzyme activities as integrative indicators of soil health. In: Pankhurst CE, Doube BM and Gupta VVSR (Eds), Biological indicators of soil health. CABI, Wellingford, p. 121-156.

FERREIRA AS, CAMARGO FAO AND VIDOR C. 1999. Utilização de microondas na avaliação da biomassa microbiana do solo. Rev Bras Ci Solo 23(4): 991-996.

FERrEIRA AS, OLIVEIRA RS, SANTOS MA AND BORGES EN. 2008. Atividade respiratória da microbiota e conteúdo de glicose em resposta à adição de fósforo em solo de Cerrado. Rev Bras Ci Solo 32(5): 1891-1897.

Fioretto A, PAPA S, PELlEGRINO A AND FERRIGNO A. 2009. Microbial activities in soils of a Mediterranean ecosystem in different successional stages. Soil Biol Biochem 41(10): 2061-2068.

GELLER IT AND GINZBURG KY. 1979. Determination of the phosphatase activity of various soil groups Soviet. Soil Sci 11(1): 44-51.

GERRITSE RG AND VAN DUK H. 1978. Determination of phosphatase activities of soils and animal wastes. Soil Biol Biochem 10(6): 545-551.

HENRY HAL. 2012. Soil extracellular enzyme dynamics in a changing climate. Soil Biol Biochem 47: 53-59.

HUANG Q AND SHINDO H. 2000. Effects of copper on the activity and kinetics of free and immobilized acid phosphatase. Soil Biol Biochem 32(13): 1885-1892.

HUI D, MAYES MA AND WANG G. 2013. Kinetic parameters of phosphatase: A quantitative synthesis. Soil Biol Biochem 65: 105-113.

IRVING GCJ AND COSGROVE DJ. 1976. The kinetics of soil acid phosphatase. Soil Biol Biochem 8: 335-340.

KÖPPEN W. 1923. Die klimate der Erde. Walter de Gruyter \& Co., Berlin, Leipzig, 369 p.

MALCOM RE. 1983. Assessment of phosphatase activity in soils. Soil Biol Biochem 15(4): 403-408.

MARINARI S, MASCIANDARO G, MCCANTI B AND GREGO S. 2008. Kinetics of acid phosphatase in calcium chloride extractable soil organic matter. Soil Biol Biochem 40(9): 2076-2078. 
MARX MC, WOOD M AND JARVIS S C. 2001. A microplate fluorimetric assay for the study of enzyme diversity in soils. Soil Biol Biochem 33(12): 1633-1640.

NANNIPIERI P, CECCANT B, CERVELli S AND CONTI C. 1982. Hydrolases extracted from soil: kinetic parameters of several enzymes catalysing the same reaction. Soil Biol Biochem 14(5): 429-432.

NANNIPIERI P AND GIANFREDA L. 1998. Kinetics of enzyme reactions in soil environments. In: Huang PM, Senesi N and Buffle J (Eds), Structure and surface reactions of soil particles. J Wiley \& Sons, New York, p. 449-479.

Neble S, CAlvert V, Le Petit J AND CRiQuet S. 2007. Dynamics of phosphatase activities in a cork oak litter (Quercussuber L.) following sewage sludge application. Soil Biol Biochem 39(11): 2735-2742.

NOVAIS RF AND SMITH TJ. 1999. Fósforo em condições tropicais. Viçosa, MG: UFV, 399 p.

PAVANELli LE AND ARAÚJo FF. 2010. Parâmetros químicos e biológicos indicadores de qualidade de solo sob cultivo de braquiárias e soja no oeste paulista. Rev Ceres 57(1): 118-124.

PETTIT NM, GREGORY LJ, FREEDMAN RB AND BURNS RG. 1977. Differential stabilities of soil enzymes. Assay and properties of phosphatase and arylsulphatase. Biochim Biophys Acta 485(2): 357-366.

SEGEL IH. 1975. Enzyme Kinetics. Behavior and Analysis of Rapid Equilibrium and Steady-state Enzyme Systems, New York: Wiley.

STOTZKY G. 1965. Methods of soil analysis, Part II, American Society Agronomy, Madison, Wisconsin (1965), p. 15501570. Microbial respiration. In: Black CA (Ed).
SYlVIA D, FUHRMANN J, HARTEL P AND ZUBERER D. 1999. Principles and applications of soil microbiology, New Jersey, Prentice Hall.

TABATABAI MA. 1994. Soil enzymes. In: Weaver RW, Angle JS and Bottomley PS (Eds), Methods of soil analysis, part 2. Microbiological and biochemical properties. SSSA Book Series No. 5. Soil Sci Soc Am Madison, Wis., p. 775-833.

TABATABAI MA AND BREMNER JM. 1969. Use of p-nitrophenyl phosphate for assay of soil phosphatase activity. Soil Biol Biochem 1: 301-307.

TRASAR-CEPEDA MC AND GIL-SOTRES F. 1988. Kinetics of acid phosphatase activity in various soils of galicia (NW Spain). Soil Biol Biochem 20(3): 275-280.

USDA - UNITED STATES DEPARTMENT OF AgRiCUlTURE. 1992. Soil Conservation Service. Soil Taxonomy: A basic system of soil classification for making and interpreting soil surveys. Agric. Handbook 436. USDA, Washington, DC.

VinHAL-FreitAs IC, FERREIRA AS, CORRÊA GF AND WENDLING B. 2012. Influence of phosphorus and carbon on soil microbial activity in a savannah agroecosystem of Brazil. Comm Soil Sci Plant Anal 43(9): 1291-1302.

VINHAL-Freitas IC, FERrEIRA AS, CORREA GF AND WENDLING B. 2013. Land use impact on microbial and biochemical indicators in agroecosystems of the Brazilian Cerrado. Vadose Zone J 12(1): 1-8.

VINHAL-FREITAS IC, WANGEN DRB, FERREIRA AS, CORRÊA GF AND WENDLING B. 2010. Microbial and enzymatic activity in soil after organic composting. Rev Bras Ci Solo 34(3): 757-764. 